\title{
Multiple actor orientation: a case study of groundnut in Anantapur, Andhra Pradesh
}

\author{
V.L. Prasad, P.G. Bezkorowajnyj, S.N. Nigam, J. \\ Hanson and D. Romney
}

\begin{abstract}
As part of a three-year project focusing on improving the livelihoods of poor livestock keepers by improving the availability of fodder, new groundnut varieties were tested, incorporating participatory rural appraisal (PRA), rapid rural appraisal (RRA), focus group discussions (FGDs) and field days as learning platforms. These approaches had limitations in addressing the complexity of the groundnut farming system and therefore constraints to the uptake of improved varieties continued to elude solution. The potential of a multi-stakeholder approach to gain a broader view of how novelty and innovation occur in a farming system was then recognized. Interactions among a range of actors including, among others, traders, oilseed merchants and private seed companies, were facilitated within a process of action and reflective learning. As a result, new constraints to innovation in groundnut varieties were identified and ways of overcoming them were noted.

Documentation and analysis of the type and quality of linkages between the actors in the system helped to catalogue the process, and the platform thus created provided the actors with an opportunity to learn from each other. The lessons and implications are discussed.
\end{abstract}

Keywords: groundnut varieties; farming innovation; fodder; rural poverty; stakeholder linkages; Andhra Pradesh

V.L. Prasad (corresponding author) is a Visiting Scientist and P.G. Bezkorowajnyj is Project Manager with the Fodder Innovation Project at the International Livestock Research Institute (ILRI), ICRISAT Campus, Patancheru 502324, Andhra Pradesh, India. E-mail: leelaprasad.v@gmail.com; p.bezkorowajnyj@cgiar.org. S.N. Nigam is a Scientist at the International Crops Research Institute for the Semi-Arid Tropics (ICRISAT), Patancheru 502324, Andhra Pradesh, India. E-mail: s.nigam@cgiar.org. J. Hanson is Project Leader, Forage Diversity at ILRI, Addis Ababa, Ethiopia. E-mail: j.hanson@cgiar.org. D. Romney is with CABI Africa, ICRAF Complex, United Nations Avenue, Gigiri, PO Box 633-00621, Nairobi, Kenya. E-mail: d.romney@cabi.org.

Groundnut (Arachis hypogaea L.) haulms are an important source of fodder in mixed farming systems in the semiarid zones of Andhra Pradesh and other states of India. In south-western Andhra Pradesh, which includes the Anantapur district, cattle production depends mainly on this source of fodder (ISPA, 1997). Groundnut is also grown as a food-feed crop in other developing countries, providing pods for human consumption and haulms for livestock feeding (Larbi et al, 1999; Omokanye et al, 2001). India ranks first in the extent of groundnut cultivation, with 6.7 million ha, followed by China, Nigeria and the USA. In total production, it ranks second, with 5 million $t$, behind China, which produces 10 million $t$ (Talwar, 2004). Among the states of India, Gujarat tops the production list with over one million $t$, closely followed by Tamil Nadu and Andhra Pradesh (AP), with slightly less than one million $t$ each (AP Oil Federation, 2005).

Within AP, Anantapur district is the highest groundnut producer, with 0.28 million $t$, or about $34 \%$ of the production in the state. However, productivity is low $\left(0.27 \mathrm{t} \mathrm{ha}^{-1}\right)$. 
Mean rainfall in the district is about $550 \mathrm{~mm}$, which is erratic both in space and time. The monthly potential evapotranspiration is more than the monthly normal rainfall, which reduces the soil moisture and makes agriculture a risky proposition in this district (Government of Andhra Pradesh, 2004).

The results from dual-purpose usage, groundnut crop improvement and livestock nutrition programmes conducted by ICRISAT/International Livestock Research Institute (ILRI) have shown that choosing appropriate cultivars could substantially improve the food and fodder situation in mixed crop-livestock systems (Ramakrishna Reddy et al, 2004; Blummel et al, 2005a). For instance, significant differences have been reported for organic matter digestibility, organic matter intake and live weight gain in sheep fed with 13 different cultivars of groundnut with a three-fold variation in live weight gain across the cultivars. It was concluded from these findings that livestock productivity in mixed crop-livestock systems could be substantially improved through the provision of superior dual-purpose cultivars (Vellaikumar et al, 2004). Similarly, relationships between haulm fodder quality traits and pod and haulm yields in 860 genotypes suggested that high pod yield and superior haulm quality were compatible traits (Blummel et al, 2005b). Participatory evaluation trials of nine improved varieties and a local control, carried out during the rainy seasons of 2002 and 2003 in two villages of Anantapur district, indicated that, of the new varieties, ICGV 91114 gave higher fodder yields of $7.7 \%$ and $12 \%$ in the two seasons respectively, and stable or increased pod yields of $0 \%$ and $17 \%$ respectively. Other benefits observed included greater disease resistance, shorter maturation times and higher shelling percentage (ICRISAT, 2004). About 70\% of rural households in India keep livestock, and income from livestock accounts for $15-40 \%$ of total farm household income (World Bank, 1999). It might be assumed, therefore, that improved cultivars of groundnut that promise higher pod and haulm yields are likely to be adopted by farmers, as they would help improve livestock-based livelihoods.

A project entitled 'Enhancing Livelihoods of Poor Livestock Keepers through Increasing Use of Fodder', supported by the UK Department For International
Development (DFID), was started in September 2002 in India. Its main objective was to increase the productivity of livestock and the sustainability of farming systems through adoption of fodder innovations. The project, which involved both civil and public-sector organizations, began with diagnostic surveys and participatory varietal selection (PVS) including focus group discussions to identify farmer practice and understand farmer needs, followed by researcher-designed, farmer-managed onfarm trials.

In the initial design of the project, it was envisaged that the most promising of the farm-tested varieties would be scaled up through farmer-to-farmer transfer of technology. However, constraints to scaling up arose, and it became clear that there were issues beyond the farm gate that had to be considered. This paper is an attempt to present the change-of-learning approach adopted by the initiative. It is organized into five sections. The next section summarizes the sample survey conducted to characterize the crop-livestock farming system. The subsequent two sections, respectively, provide information obtained through PVS and explore the lessons learnt from a multistakeholder workshop conducted in preparation for the scale-up. Impact pathways for the groundnut scale-up based on an innovation systems analysis are presented in the penultimate section. Finally, a strong case is made for the Innovation Systems approach in the concluding section.

\section{Diagnostic survey}

A sample survey was conducted with 60 farming households from three villages in Uravakonda mandal [subdistrict] of the Anantapur district. The purpose was to understand and characterize the livestock-livelihoodsfodder scenario from a farming systems perspective. Another objective was to explore how far the prevailing crops and cropping systems supported the fodder requirement of cattle through the different seasons of the year. The three villages of Sivapuram, Veligonda and Yerraborepalli have several typical features: red loamy soils, predominantly rainfed agriculture and groundnutbased cropping. Also, the majority of their households are

Table 1. Cattle holding and fodder situation of farmers belonging to various strata with respect to landholding, caste and irrigation $(\mathrm{N}=60)$.

\begin{tabular}{|c|c|c|c|c|c|c|c|c|}
\hline Farmer category & & $\begin{array}{l}\text { Number of } \\
\text { households }\end{array}$ & $\begin{array}{l}\text { Mean land- } \\
\text { holding (ha) }\end{array}$ & $\begin{array}{l}\text { Number of } \\
\text { cattle }^{\text {b }} \text { per } \\
\text { household }\end{array}$ & $\begin{array}{c}\text { Mean total } \\
\text { stall-fed } \\
\text { fodder }(t)\end{array}$ & $\begin{array}{l}\text { Groundnut in } \\
\text { total stall-fed } \\
\text { fodder }(\%)\end{array}$ & $\begin{array}{l}\text { Purchased } \\
\text { fodder }(\%)\end{array}$ & $\begin{array}{c}\text { Farmers who } \\
\text { purchased } \\
\text { fodder }(\%)\end{array}$ \\
\hline \multirow{5}{*}{ Landholding (ha) } & Up to 1 & 4 & 0.7 & 1.3 & 0.2 & 95 & 73.3 & 50 \\
\hline & $1.1-2.0$ & 15 & 1.7 & 2.2 & 1.5 & 91 & 36.8 & 73 \\
\hline & $2.1-4.0$ & 15 & 3.6 & 3.2 & 2.2 & 88 & 19 & 66.7 \\
\hline & $4.1-8.0$ & 14 & 6 & 4 & 3 & 78 & 19.2 & 64.3 \\
\hline & $>8$ & 12 & 15.2 & 6.8 & 5.1 & 71 & 21.2 & 83.3 \\
\hline \multirow[t]{2}{*}{ Irrigation status } & Rainfed & 38 & 5.8 & 3.3 & 2.2 & 81 & 31.4 & 81.6 \\
\hline & Irrigated $^{\mathrm{a}}$ & 22 & 5.8 & 5 & 3.5 & 80 & 13.3 & 72.7 \\
\hline \multirow[t]{3}{*}{ Caste groups } & $\mathrm{SC}$ & 16 & 2.5 & 2.7 & 1.1 & 94 & 29.3 & 62.5 \\
\hline & $\mathrm{BC}$ & 38 & 6.1 & 4.2 & 2.9 & 83 & 22.5 & 68.4 \\
\hline & OC & 6 & 12.4 & 5 & 5.4 & 69 & 19.6 & 100 \\
\hline Overall & & 60 & 5.8 & 3.9 & 3 & 79 & 22.6 & 70.0 \\
\hline
\end{tabular}

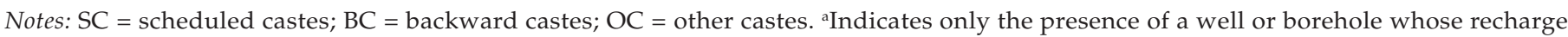
is highly dependent on rainfall. ' Includes buffaloes and cattle of all age groups. 
poor. The respondent farmers, both men and women, were drawn randomly from a sample stratified on the basis of caste, size of land and cattle holding and access to irrigation. Trained field investigators administered a structured questionnaire. The sample represented $10 \%$ of the households in the three villages.

The survey showed that cattle were kept for various purposes: to meet the draught requirements of groundnut farming; as a source of cash income by hiring out draught services to others; for the production of milk for home consumption; to serve banking and insurance functions through the sale of animals in times of emergency - for example, to defray medical expenses and/or tide farmers over crop failures in droughts. It was also learnt that the shortage of fodder could be so acute that a majority of farmers, including the poor, would buy crop residues to feed their animals, particularly during April-June (Table 1 ). There was a meagre $0.75 \mathrm{t}$ of stall-fed fodder per animal, of which $79 \%$ was groundnut haulm. Seventy per cent of the farmers purchased dry fodder to cope with the shortage of home-grown fodder; of these, two-thirds purchased paddy straw and the remainder groundnut haulm. In addition to being used as fodder, paddy straw acts to stabilize the haulms when stacked and serves as a shelter from the rain. The survey indicated that, given the low rainfall and virtual monocropping of groundnut in Anantapur, an improved variety of groundnut that could yield more pods and haulms with higher haulm quality compared with the prevailing local variety would enhance the livelihoods of crop-livestock farmers.

\section{Participatory varietal selection}

In the light of the findings of the survey, focus group discussions were held mainly with farmers practising rainfed agriculture in the three villages to elicit options for improving livestock-related and fodder-related livelihoods. The farmers indicated that dual-purpose groundnut varieties would be an effective way to address the fodder shortage. Accordingly, 75 farmers, the majority of them smallholder farmers practising rainfed agriculture, were provided with seeds of ICGV 91114, a variety specially bred by ICRISAT for low-rainfall areas. The farmers cultivated the improved variety and the local cultivar over half an acre each in comparable and contiguous patches of land. They used their own practices for both varieties. Field days with neighbouring farmers visiting plots just before harvesting and simple household-level questionnaires (HLQs) after harvesting were used as learning platforms to see how the farmers perceived the performance of the new variety.

During the field days, using matrix scoring, test farmers and visiting farmers rated the test cultivar as superior to the local variety based on their own criteria (Table 2). Analysis of the post-harvest questionnaires provided a similar picture.

\section{Preparations for scale-up}

A multi-stakeholder workshop was conducted in the district to streamline and organize the scale-up and scaleout of the improved cultivars that had been tested in the PVS studies. Apart from farmers from the project villages, participants in the workshop included researchers, representatives from government departments, public and private seed companies, non-governmental organizations (NGOs), the Krishi Vigyan Kendra (KVK) and other civil sector actors.

The workshop highlighted the fact that adequate seed systems, formal or informal, were not yet in place to support the envisaged scale-up. While most farmers save their own seed to meet their seed requirements, smallholder farmers in particular have serious difficulty in doing so, owing to financial problems and debt-servicing pressures at the time of harvest. Fear of spoilage of seed during storage (6-7 months) is another challenge in maintaining seed sustainability. The government is a key player in seed supply, but its supplies are fraught with problems - such as restrictions on the quantity that can be supplied per farmer (only $120 \mathrm{~kg}$ ), lack of varietal purity and the enormous logistical expenditure due to the bulky nature of pods. Other problems relate to middlemen and traders who supply part of the seed requirement at the onset of the season and also procure groundnut at harvest time. Farmers perceive that traders adopt unfair practices when weighing, pricing and determining the qualityrelated aspects at both buying and selling stages. The contrasting preferences of different actors are also

Table 2. Farmers' ranking of two groundnut varieties $(\mathrm{N}=45)$.

\section{Farmer-identified traits Indicators recorded by farmers}

Flowering performance Heavy pods

Rounded, heavy kernel

Taste of kernel

Branches and leaves

Empty pods

Pests and diseases

Duration of crop

Pods per plant

Total score

Rank
Height of plants
Less than 40 days, uniformly thick yellow flowers which do not turn red or fall off Heaviness of pods signifying kernels inside

Not misshapen, shrivelled or shrunken

Tasty; not bitter

More branches and dark green leaves without pests

Not more than $5 \%$

Should be free from aggitegulu (rust and leaf spot) and gudamategulu (sclerotium rot)

Less than 90 days

Not fewer than 25 pods

About $1 \mathrm{ft}$, not more and not less
Control Test cultivar (ICGV 91114) (TMV 2)

Note: The ranking was scored on a scale of $1-10$, with $1=$ worst and $10=$ best, in 2004 . 
problematic: for example, millers prefer groundnut with higher oil content, whereas smallholder farmers prefer smaller-kernel varieties because of their drought tolerance.

The workshop deliberations were an eye-opener in that they showed that scale-up of a new technology could not be taken for granted. Instead, certain processes must be taken into account involving various actors and factors that may be within or outside the control of a research initiative. The project felt the need for a more comprehensive learning approach that was not solely concerned with the demand aspects at farmer's level but also took account of the mandates and needs of all the actors involved in supply, demand, trade and other support services.

\section{Analysis of the groundnut innovation system}

An Innovation Systems Analysis (ISA) was built up through a series of key informant interviews with different actors, and resulted in actor analysis, actor linkage analysis and problem analysis, broadly following the tools of the Actor Linkage Matrix (ALM) developed by Biggs and Matsaert (2004) and the Rapid (or Relaxed) Appraisal of Agricultural Knowledge Systems (RAAKS) developed by Salomon and Engel (1997). The information base for the ISA comprised individual interviews, group discussions with public-sector personnel from the AP Oil Federation and the state government's Department of Agriculture, discussions with private-sector actors including three millers, two decorticating unit owners, one trade intermediary (Siddeswar \& Co, Anantapur) and two village-level traders, and discussions with 40 farmers from the villages of Sivapuram and West Narasapuram. The actors' views were also captured in the multistakeholder workshop mentioned above, in which project personnel encouraged them to air their views on problems and opportunities in groundnut-based livelihoods.

\section{Actors in the groundnut system}

Public, private and civil sectors were identified as well as members of the Legislative Assembly (MLAs) and mem- bers of Parliament (MPs) (Table 3). Apart from farmers, who are the principal stakeholders, actors included the district administration represented by the Collector and a number of functionaries working at the district and mandal level; the AP Oil Federation and two other seed distribution agencies; the Joint Director of Agriculture and his team; and a vast chain of private-sector traders dealing with chemicals, procurement and sale of groundnut.

A leading NGO, Rural Development Trust Accion Fraterna (RDT-AF), with its network of functionaries across the district, is also closely involved in improving groundnut-based livelihoods.

\section{Actor linkages}

In general, the strength of a linkage indicates how well an actor is connected with others. Strong linkages enable actors to communicate and work together and may involve exchange of resources such as information, labour or other materials that promote goodwill. By and large, the actors within the government framework were found to be well connected. These linkages reflected formal, hierarchical and functional relations that tend to ensure a unified line of command, as in the case of the District Collector's relations with the AP Oil Federation, the Department of Agriculture and mandal staff. They were found to be very effective in ensuring functions such as seed distribution, which has to be executed with strict deadlines to ensure timely seed delivery. However, when it came to relations with smallholder farmers, the publicsector actors in general did not have strong linkages. For instance, the agricultural officer concerned with technical advice and extension did not have adequate linkages with farmers. This was apparently due to inadequate outreach, given the vast number of farmers and their geographical spread. These weaker interactions and linkages were also due to ineffective institutional arrangements, which were responsible for the lack of functional formal forums in which farmers could air their problems, views and perceptions.

In contrast, traders associated with the sale of fertilizers and pesticides - dealers and retailers - had strong

Table 3. Broad categories of actors and their mandates in the groundnut farming system.

\section{Actors}

Smallholder farmers

Medium-scale and large-scale farmers

District administration

AP Oil Federation

Department of Agriculture (Joint Director and others)

\section{District Water Management Association (DWMA)}

Private seed dealers in seed, fertilizer, pesticide and agricultural implements

Wholesale traders from Tamil Nadu and other states Local and intermediary traders

Credit institutions

Rural Development Trust and other NGOs

Elected representatives

\section{Mandate/mission}

To make a living from groundnut, wage labour and livestock

To make a living from diversified farm and non-farm sources such as services and business

Preparing overall plan and implementing it with focus on seed distribution

Mainly concerned with seed distribution for the rainy season; seed procurement and formulation of the minimum support price

Assisting the government with seed distribution; providing technical advice and extension to farmers; implementing other agricultural programmes in the district

Developing watersheds, enhancing productivity of agriculture and enhancing income from livelihoods

To provide support services, extension, counselling; also often to provide credit

To buy groundnut on a large scale as pods/kernels

To procure at the village level and sell to decorticating units/millers/exporters

To provide timely credit to farmers

Watershed development, technical advice and crop demonstrations

Members of Legislative Assembly (MLAs) and members of Parliament (MPs) 
linkages with farmers, and vice versa. Farmers often sought technical advice from them. While functioning as an important source for communication and extension, these input suppliers operate at different levels in league with the village-level traders who procure groundnut. They also offer credit to farmers. However, strong linkages do not necessarily mean a win-win situation. Credit, material supplies, technical advice and procurement of groundnut become interlinked, often to the greatest disadvantage of smallholder farmers. This is where institutional and policy matters need to be examined to improve the innovation process.

Finally, linkages between traders and government were found to be weak and almost non-existent. There is no formal regulative mechanism at the market level, and no regulated market exists for groundnut kernels in Anantapur. As a result, traders rule the roost and control the pricing mechanism and the weighing practices, often to the detriment of farmers. Linkages among smallholder farmers were strong but limited to informal interactions. Formalized interactions at the level of the village organization or watershed association leading to an interface with government-related or trade-related actors were nonexistent.

\section{Prime mover hexagram}

Prime mover or stakeholder analysis often indicates which actors have more power or are more influential in driving change - for better or worse. Coalitions are usually seen among actors with influence. A prime mover hexagram was developed with the help of a group of actors, which included personnel from the AP Oil Federation, the Department of Agriculture, private traders and farmers. These respondents first identified the actors and scored their individual influence on a scale of $1-10$. The actors were then grouped on a functional basis and a score was assigned to the group.

Figure 1 shows that market-related actors (mainly from the neighbouring state of Tamil Nadu) who buy the bulk of the groundnut from Anantapur have the greatest influence. They operate through a long chain of villagelevel traders, brokers and commission agents, decorticating unit owners and others. The other lead actors are government agencies such as AP Oil Federation and the district administration, which are associated with the subsidized seed supply programme. Large-scale farmers, who are associated with trade, credit and

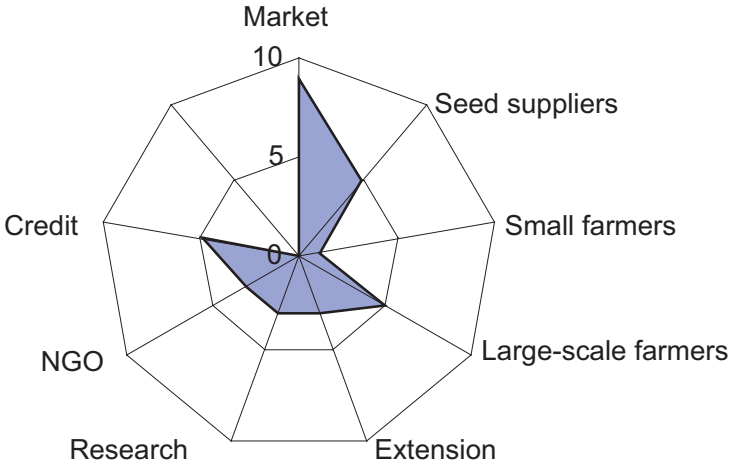

Figure 1. Prime mover hexagram of the Anantapur groundnut farming system.

political power, are also lead players. Research and extension do not play a dominant role. Smallholder farmers, who are perhaps the most important group from the development and equity point of view, are predictably the least powerful. Village organizations and watershed associations are not influential enough to access and establish efficient links to alternative - and in some cases more appropriate - services to meet their needs.

\section{Actor-factor interactions and problem analysis}

Farmers and other actors, representing input suppliers, technical advice and trade, separately listed and ranked the problems from their viewpoint and subsequently ranked them as one group and discussed the actor-factor interactions for each issue. The results of this analysis included the overall ranking of the problems, the importance of the actors concerned in addressing them and the factors responsible for them (Table 4). Next to drought, the absence of organized market yards seemed to be the major problem. Other trade-related issues were allied to this problem: constituting a marketing committee manned by all the stakeholders; putting in place a framework of rules related to buyers and sellers; making available the required physical infrastructure; making arrangements for scrupulous weighing and measurement; instituting and implementing price premiums and penalties vis-à-vis groundnut quality; and widely communicating and displaying information on market intelligence.

Table 4. Ranking of problems and factors by the actors concerned.

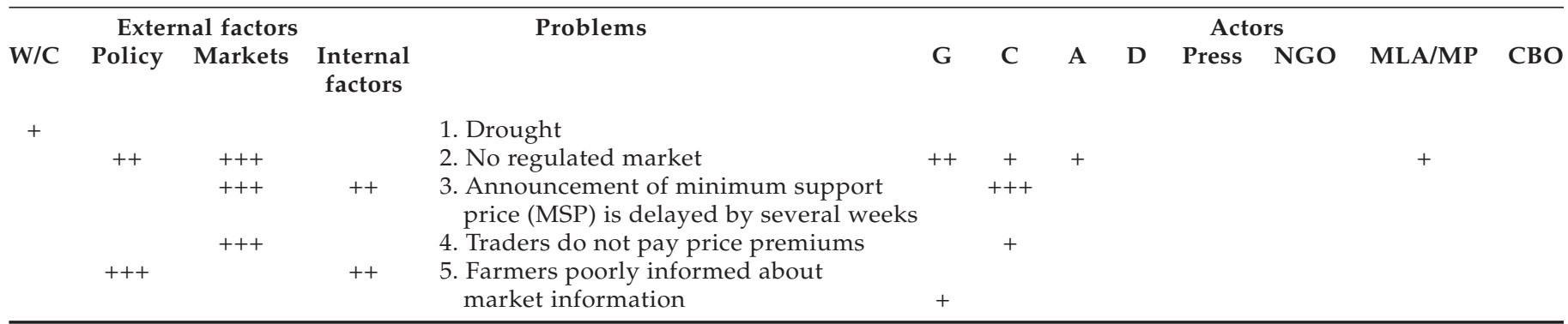

Note: The number of 'plus' signs indicates the extent of responsibility. $\mathrm{G}=$ government; $\mathrm{C}=\mathrm{Collectors} ; \mathrm{A}=\mathrm{AP}$ Oil Federation; $\mathrm{D}=$

Department of Agriculture. 
The overemphasis on subsidized seed supply, according to the actors themselves, is due to populist government policies. They argued that, instead of indiscriminately increasing the quantities of subsidized seed supply, the government should make the decision on the basis of an objective estimation with special reference to the prevalence of drought in the previous season, which is an important criterion for assessment of the seed requirement.

In general, farmers save seed for the next season. However, debt and fear of seed spoilage in storage have forced them to discontinue this practice. Similarly, farmers who grow groundnut on leased land may not save seed because of uncertainty over the future of the lease. In any case, many of the concerned actors suggested a drastic reduction of the subsidized seed supplies to about $10 \%$ or $20 \%$ of the present quantity, depending on the prevalence of drought in the previous season. The actors felt that an overemphasis on seed distribution drained resources that could otherwise be used for organizing more effective support services such as pest management; in fact, the pest menace has tended to worsen as farmers use large quantities of seed brought from outside.

\section{Configuration of the groundnut innovation system}

Configuration refers to a particular arrangement of actors. The groundnut innovation system in Anantapur reflects collective rather than individual competence. While actors in a system are interdependent, they are also guided by their own objectives, which might be complementary to or competitive with those of other actors. A well coordinated service resource coalition is available in the Anantapur system where the District Collector oversees seed distribution led by the AP Oil Federation, personnel from the district administration and those from the Agriculture Department deployed for the purpose. Personnel from different disciplines share objectives and tasks, execute activities and achieve outputs as laid out in the circular specially issued for the purpose by the Collector. The standardization of norms aids effective coordination of this time-bound activity. Strong political will is another facilitating factor.

However, the government-dominated seed supply programme has not been sensitive to the varietal requirements of farmers in different agro-ecological contexts within Anantapur district, besides being a deterrent to the entry of the private sector into this area. It would therefore augur well to have a public-private-civil sector partnership-based arrangement for seed supply. It is now for the actors themselves to enhance the resource coalition and gear up the convergence and coordinating mechanisms to address other problems of trade, pest management at the farm level, credit, seed storage, etc. An organized, regulated market may be the appropriate mechanism to bring about public-private partnership by way of improving innovation performance and by having market committees manned by all the concerned actors such as farmers, traders, government personnel and NGO/CBO representatives. The policy makers (who are themselves actors) might put in place the necessary conditions to improve the innovation process. The nonactors, students of the innovation system, may assist the actors in designing how they can cooperate to achieve this end. This may mean a series of changes at different levels.

\section{Conclusions and implications for research}

The change in the learning approach, from farmer-participatory varietal selection and a farmer-biased survey to a multi-stakeholder perspective, has important implications for scale-up of improved groundnut technology in particular, and for the research process per se in general. The spread of an innovation from farmer to farmer, from community to community, from village to village is often referred to as a 'scale-out'. The concept has geographical and spatial connotations. The term 'scale-up', however, usually pertains to institutional expansion from grassroots organizations to policy makers, donors, development institutions and other stakeholders and arrangements, which are key to supporting and building an enabling environment for change. Scale-up and scaleout are interrelated concepts; as a change spreads geographically, its chances of influencing those at higher institutional levels are greater, and vice versa; and as one reaches higher institutional levels, the chances of horizontal spread increase.

The scale-up approach argues that solutions to complex problems cannot be found on-station only, but need to be discovered in situ in farmers' fields as well, taking full advantage of their knowledge and innovative abilities. Farmers usually make changes in their systems to adapt to new technological interventions and similarly modify technology packages to adapt them to their systems (Douthwaite et al, 2003a). Also implicit in the concept of scale-up is the proposition that technological change is brought about by the formation and actions of networks of stakeholders/actors. The actors may belong to the public sector (government/banks), private sector (seed companies or private individuals/moneylenders/traders) and/or the civil sector (NGOs/CBOs). So whatever in situ modifications and improvisations farmers achieve on the best-bet technologies provided to them have to be understood in light of these processes (Douthwaite et al, 2001). Given this understanding, the researcher or development practitioner will be able to target other areas where farmers' innovations can be introduced. In other words, scale-up replicates the social and organizational processes associated with technical change rather than technology per se. An appreciation of farmers' adaptations in light of associated processes is also required if effective support is to be provided to farmers and an enabling environment created.

This implies that on-farm trials cannot be one-off attempts to validate station-bred technologies, but have to be taken as learning opportunities for farmers to construct their technologies in the 'learning-by-doing' mode. Farmers also communicate what they learn to other farmers with whom they share or pass on seeds or planting material. The resource endowment, the agro-ecological context in which farmers live and their linkages with other actors dictate the type of adaptations farmers make before large-scale adoption of technologies takes place. For example, in the context of the groundnut variety in Anantapur, farmers' perceptions and ranking of the improved variety were based on just one season's experience on 0.2 ha of land. With many farmers having more than 2 ha, there is a need for more iterative experiential learning between and among input suppliers, 
traders, farmers and others before the change to the improved variety can occur. In the first place, farmers should be convinced of the availability of seed in time and that traders will pay well for the improved variety when produced in larger quantities. The traders, for their part, need to be assured that the quantity of improved kernel reaching the market will be large enough for them to make necessary modifications in their equipment (sieve sizes, etc).

The way out of this problematic situation is to enhance linkages among actors to provide for knowledge and information flows. Innovation is created within a network of actors that co-evolves with the technologies it generates (Nelson, 1993; OECD, 1999; Rycroft and Kash, 1999). Coevolution occurs as a result of iterative experiential learning among the actors involved (Rosenberg, 1982) that is intrinsically random (Kauffman, 1995). Fostering scaling up and out is therefore best done by first identifying the key stakeholders - the people who will ultimately benefit from the innovations and those responsible for their promulgation - and then working with these stakeholders in a participatory way to encourage them to take over ownership. If this happens, the key stakeholders will tend to promote the innovation to each other and will lobby for political support for it, even if there are setbacks and funding cuts. Successful innovations result from strong interactions and knowledge flows within these networks (Douthwaite et al, 2003b).

Of late, research funders have been asking for more concrete evidence of the impacts of agricultural research. Their concern is reflected in the term 'impact orientation', a normative concept that is increasingly used to characterize an organization which has managed to achieve outcomes and impacts and not merely outputs (GTZ, 2000; Smith and Sutherland, 2002). Impact orientation refers to client-oriented research methods, responsiveness and linkages to farmers and other stakeholders in pursuit of development goals (SpringerHeinze et al, 2003). The typical impact pathway so built is unlikely to comprise a single chain of events leading, in a deterministic mode, to the inevitable impact. Instead, the pathway will simulate multiple chains of events, with 'influencing and dependent' events occurring and with certain probabilities underlying the inevitable uncertainties and risks. In other words, there are social and organizational processes associated with each stage - from activities through outputs, outcome and impact - each of which entails the next stage only after satisfying 'if-then' conditions.

Similarly, while there are factors that are controlled by activities and actions planned and implemented, there are also factors outside the control of the 'plan-act' arena of any R\&D initiative. These could be climatic, marketrelated aspects or policy changes. They might influence the planned initiative either positively or negatively. Therefore, it is clearly imperative for the organization concerned to take into account the host of events required to be facilitated, monitored and measured. More important than using the pathway as a roadmap for monitoring progress, it should be seen as a tactical knowledge management tool that is built by reconstructing the reality proactively. In this way, it will help to account for the smaller occurrences of 'change' likely to result from the actor-factor interaction processes at each stage. Building such a plausible bridge at the beginning of a project will help to identify scale-up-and-out pathways and better predict the likelihood of the success of the project.

Conversely, in the PVS and technology transfer mode, the ex ante analysis of the farmers' context (captured through surveys, focus group discussions and on-farm trials) was considered adequate for the scale-up of the test variety. In the 'real world' situation, however, it was not. There were no suitable seed systems in the district to backstop the scale-up process. At present, the produce of farmers is recycled for seed and no certified seed development process has been initiated. The seed spoilage problems of smallholder farmers must therefore be addressed to ensure the sustainability of groundnut farming, while trade regulations need to be in place so that farmers receive their due in the market. The innovation systems framework of analysis brought out many issues pertaining to the groundnut system as a whole, while the PVS approaches highlighted the importance of germplasm to the neglect of others. The next step is to explore ways of building the capacity of the system so that it is better able to access and adapt new technology. This may mean facilitating new coalitions of actors that formerly did not interact, and building the capacity of individuals and organizations to understand the nature of the problems faced beyond the technological problem.

In summary, the importance of recognizing that many and various actors are involved in technology development, adaptation and transfer is now clear, as is the need to promote better information flow among those actors to improve the performance of the wider innovation system. The current interest in understanding innovation systems around particular technical interventions emerges from the work of a number of scholars. Notable among these are the Agricultural Knowledge and Information System (AKIS) ideas proposed by Röling (1994); the Multiple Sources of Innovation model of agricultural research and technology promotion by Biggs (1990) and the National Systems of Innovation approaches articulated by Freeman (1987) and Lundvall (1992). One of the major contributions of this framework is that it explicitly recognizes the wide range of actors - in research institutions and elsewhere - involved in innovation and the institutional context in which they interact. The framework also emphasizes the importance of linkages, partnerships, alliances and coalitions among the various actors, the value of technological and institutional innovations and the role of learning in promoting better innovation systems (Hall et al, 2000). The main argument of this paper is that the adoption of such a framework is now necessary in order to ensure that pro-poor interventions actually reach the targets envisaged.

\section{Acknowledgments}

This report is an output of a research project funded by the UK Department for International Development (DFID) for the benefit of developing countries. The views expressed are not necessarily those of DFID. The authors are grateful to Dr Malla Reddy of RDT for his support in implementing the project and Dr Norman Clark for his comments and suggestions on the manuscript. 


\section{References}

AP Oil Federation Limited (2005), Groundnut Crop: Tips for Improving Productivity, Report from the Managing Director, AP Oil Federation, Basheerbagh, Hyderabad.

Biggs, S. (1990), 'A multiple source of Innovation Model of Agricultural Research and Technology Promotion', World Development, Vol 18, No 11, pp 1481-1499.

Biggs, S., and Matseart, H. (2004), Strengthening Poverty Reduction Programmes Using an Actor-Oriented Approach: Examples from Natural Resources Innovation Systems, AgREN Network Paper No 134, ODI Agricultural and Research Network, London.

Blummel, M., Ramakrishna Reddy, Ch., Ravi, D., Nigam, S. N., and Upadhyaya, H. D. (2005a), 'Food-fodder traits in groundnut', International Arachis Newsletter, Vol 25, pp 52-54.

Blummel, M., Vellaikumar, S., Devulapalli, R., Nigam, S. N., Upadhyaya, H. D., and Khan, A. (2005b), 'Preliminary observations on livestock productivity in sheep fed exclusively on haulms from eleven cultivars of groundnut', International Arachis Newsletter, Vol 25, pp 54-57.

Douthwaite, B., Delve, R., Ekboir, J., and Twomlow, S. (2003a), 'Contending with complexity: the role of evaluation in implementing sustainable natural resource management', International Journal of Agricultural Sustainability, Vol 1, No 1, pp 51-66.

Douthwaite, B. J., Keatinge, D. H., and Park, J. (2001), 'Why promising technologies fail: the neglected role of user innovation during adoption', Research Policy, Vol 30, No 5, pp 819-836.

Douthwaite, B., Kubyb, T., van de Fliertc, E., and Steffen, S. (2003b), 'Impact pathway evaluation: an approach for achieving and attributing impact in complex systems', Agricultural Systems, Vol 78, pp 243-265.

Freeman, C. (1987), Technology and Economic Performance: Lessons from Japan, Pinter, London.

Government of Andhra Pradesh (2004), 'Statistical abstracts of Andhra Pradesh 2004', Directorate of Economics and Statistics, Government of Andhra Pradesh, Hyderabad.

GTZ [Deutsche Gesellschaft für Technische Zusammenarbeit] (2000), ECART/ASARECA/CTA Workshop on Impact Assessment of Agricultural Research in Eastern and Central Africa, 16-19 November 1999, Entebbe, Uganda, Eschborn, Germany.

Hall, A. J., Clark, N. G., Sulaiman, R. V., Sivamohan, M. V. K., and Yoganand, B. (2000), 'New agendas for agricultural research in developing countries: policy analysis and institutional implications', Knowledge, Policy and Technology, Vol 13, pp 70-91.

ICRISAT [International Crops Research Institute for the SemiArid Tropics] (2004), 'Programme for farmer participatory improvement of grain legumes in rain fed Asia', Progress Reports (2002-2004): IFAD Technical Assistance Grant No. 532, ICRISAT, Patancheru, Andhra Pradesh (limited distribution).

Indo-Swiss Project Andhra Pradesh [ISPA] (1997), 'Livestock feeding situation in Andhra Pradesh - options for improvement', Indo-Swiss Project, Andhra Pradesh. VBRI premises, Shantinagar, Hyderabad.

Kauffman, S. (1995), At Home in the Universe: The Search for the Laws of Self-Organization and Complexity, Oxford University Press, New York.
Larbi, A., Dung, D. D., Olorunju, P. E., Smith, J. W., Tanko, R. J., Muhammad, I. R., and Adekunle, I. O. (1999), 'Groundnut (Arachis hypogaea) for food and fodder in crop-livestock systems: forage and seed yields, chemical composition and rumen degradation of leaf and stem fractions of 38 cultivars', Animal Feed Science and Technology, Vol 77, pp 33-47.

Lundvall, B. A., ed (1992), National Systems of Innovation and Interactive Learning, Pinter, London.

Nelson, R., ed (1993), National Innovation System: A Comparative Analysis, Oxford University Press, New York.

OECD [Organisation for Economic Cooperation and Development] (1999), Managing National Innovation Systems, OECD, Paris.

Omokanye, A. T., Onifade, O. S., Olorunju, P. E., Adamu, A. M., Tanko, R. J., and Balogun, R. O. (2001), 'The evaluation of dualpurpose groundnut varieties for fodder and seed production in Shika, Nigeria', Journal of Agricultural Science, Vol 136, pp 75-79.

Ramakrishna Reddy, Ch., Ravi, D., Nigam, S. N., Upadhyay, H. N., and Blummel, M. (2004), 'Observations on food and fodder traits in a wide range of cultivars of groundnut', in New Dimensions of Animal Feeding to Sustain Development and Competitiveness: Proceedings of V Biennial Conference of Animal Nutrition Association, National Institute of Animal Nutrition and Physiology (IAN\&P), Bangalore.

Röling, N. (1994), 'Agricultural knowledge and information systems', in Blackburn, D., ed, Extension Handbook: Processes and Practices, Thompson Educational Publishing, Toronto.

Rosenberg, N. (1982), Inside the Black Box: Technology and Econom$i c s$, Cambridge University Press, Cambridge.

Rycroft, R. W., and Kash, D. E. (1999), The Complexity Challenge: Technological Innovation for the $21^{\text {st }}$ Century, Science, Technology and the International Political Economy Series, Cassell, New York.

Salomon, M. L., and Engel, P. G. H. (1997), Networking for Innovation: A Participatory Actor-Oriented Methodology, Royal Tropical Institute, Amsterdam.

Smith, D. R., and Sutherland, A. (2002), Institutionalising Impact Orientation: Building a Performance Management Approach that Enhances the Impact Orientation of Research Organization, Natural Resources Institute, Chatham.

Springer-Heinze, A., Hartwich, F., Henderson, J. S., Horton, D., and Minde, I. (2003), 'Impact pathway analysis: an approach to strengthening the impact orientation of agricultural research', Agricultural Systems, Vol 78, pp 267-285.

Talwar, S. (2004), Peanut in India: History, Production and Utilization, Peanut in Local and Global Food Systems Series, Report No 5, Department of Anthropology, University of Georgia, Athens, GA.

Vellaikumar, S., Waliar, F., Nigam, S. N., Upadhyay, H. N., and Blummel, M. (2004), 'Effects of cultivars-dependant groundnut haulms on live weight gain and nitrogen retention', in New Dimensions of Animal Feeding to Sustain Development and Competitiveness, Proceedings of V Biennial Conference of Animal Nutrition Association, NIANEP, Bangalore, India.

World Bank (1999), India Livestock Sector Review: Enhancing Growth and Development, World Bank, Washington, DC. 